\title{
Intercropping Systems of Sunflower and Peanut under Different Irrigation Regimes and Potassium Fertilizer Levels
}

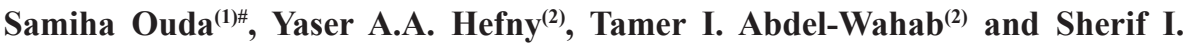 \\ Abdel-Wahab ${ }^{(2)}$ \\ (1) Water Requirements and Field Irrigation Research Department, Soils, Water and \\ Environment Research Institute, Agricultural Research Center, Giza, Egypt; (2) Crop \\ Intensification Research Department, Field Crops Research Institute, Agricultural \\ Research Center, Giza, Egypt.
}

\begin{abstract}
TWO FIELD experiments were conducted at the research farm of Ismailia Governorate, Egypt during 2016 and 2017 summer seasons. This study was used to determine the suitable spatial arrangement of sunflower and peanut in an intercropping system under three irrigation water levels and three fertilizer $(\mathrm{K})$ levels on yield, the land and water equivalent ratios and farmer's net income.

The three irrigation treatments (0.7, 1.0 and 1.2ETo), the three $\mathrm{K}$ fertilizer levels (57, 86 and $114 \mathrm{~K}_{2} \mathrm{O} \mathrm{kg} / \mathrm{ha}$ ) and the four intercropping systems of sunflower and peanut (different spatial arrangements) were arranged in a strip split plot with three replications.

The results indicated that application of 1.0 and 1.2ETo had similar effect on most of yield traits of the intercrops. Application of $114 \mathrm{~K}_{2} \mathrm{O} \mathrm{kg} / \mathrm{ha}$ had the highest values of most yield traits of the intercrops. Intercropping sunflower with peanut (S1), where peanut seeds were sown on both sides of all the raised beds, sunflower seeds were sown on one row above the raised beds and the following bed was left without intercropping gave the highest values of peanut and sunflower yield and its attributes.
\end{abstract}

In conclusion, the highest yield, land and water equivalent ratios, as well as farmer's net income can be obtained under $1.2 \mathrm{ETo}, 114 \mathrm{~K}_{2} \mathrm{O} \mathrm{kg} / \mathrm{ha}$ and $\mathrm{S} 1$ intercropping system.

Keywords: Drip irrigation, Intercropping sunflower with peanut, $\mathrm{K}$ fertilizer, Land equivalent ratio and water equivalent ratio, Farmer's net return.

\section{Introduction}

Edible oils ranked second after wheat with respect to importation in Egypt. According to the Ministry of Agriculture and Land Reclamation in Egypt, the current edible oil production-consumption gap is estimated by $97 \%$. Due to limited arable areas in the Nile Delta and Valley, emphasis should be given towards cultivation oil seed crops in new reclaimed areas to decrease oil production gap. Sunflower (Helianthus annuus L.) oil is one of the most popular edible oil in Egypt. However, its cultivated area is declining due to competition with other profitable crops. To solve this problem, sunflower can be intercropped with peanut (Arachis hypogaea L.) (two important crops in Egypt). Peanut is one of the most important suitable crops to be cultivated under sandy soil conditions. According to El-Sawy et al. (2006), intercropping sunflower in peanut cultivated area could be a solution to increase the production of oil seed per unit area. Only three studies were done locally to study the effect of intercropping sunflower as a companion crop with peanut as a main crop. Abd El-Zaher et al. (2009) reported that highest value for yield of peanut were obtained with $100 \%$ of peanut planting density and $33 \%$ of sunflower planting density. A reduced sunflower planting density, namely $25 \%$ was found to result in the highest peanut yield in sunflower intercropped with peanut system (El-Mehy et al., 2018).

Water resources in Egypt are becoming limited and scarce. To overcome this problem,

"Corresponding author email: samihaouda@yahoo.com 
introduction of irrigation system with high application efficiency, namely drip system is essential. To obtain highest yield value, increasing application of irrigation according to crop needs is required (Taha, 2012). In addition, increasing water use efficiency is another important aspect in facing water scarcity. Drip irrigation has the potential to provide high yields, conserve soil, water, and energy in the meantime. The major benefits of drip irrigation include accurate placement of water and chemicals, reduction of labor requirement, and reduction of water runoff, as well as erosion (Sorensen \& Butts, 2014).

In peanut production, irrigation in the appropriate times is important to guarantee stabilize production with high quality (Zhu et al., 2004). Because biomass productivity per unit of consumed water is known as water use efficiency (Krishnamurthy et al., 2007), increasing water use efficiency has an important role under water scarcity condition (Ouda \& Zohry, 2018).

To maximize crop yields, the amount of irrigation water and its timing are important aspects to attain the efficient use of this valuable resource (Sezen et al., 2011). It is known that availability of water can limit crop production (Genc et al., 2013). However, improving water use efficiency is necessary for securing sustainability of food production many parts of the world, particularly in semiarid areas (Medrano et al., 2015). Because of the limited water resources, changing production objectives from attaining potential yield per unit of land to attaining potential yield per unit of water is essential (Kadasiddappa et al., 2017).

Potassium contributes in various metabolic functions in plants including activation of some enzymes, photosynthesis, and protein synthesis (Hawkesford et al., 2012). It also have an important role in the development, and production (Raza et al., 2013). Potassium is one of the most important nutrients needed for peanut (Veeramani \& Subrahmaniyan, 2012). Potassim can help in mitigating water stress in peanut and its adverse effects (Umar, 2006). In soils with low potassium contents, it is peanut plants usually are highly responsive to potassium application (Almeida et al., 2015). Furthermore, Asadi (2010) indicated that application of potassium fertilizer increased sunflower yield.

Few researches were done on sunflower intercropping with peanut. However, appropriate sunflower and peanut intercropping system under application of required irrigation amounts using drip system and $\mathrm{K}$ fertilization and its role in maximize land and water use efficiency have not been studied before. Thus, the objective of this investigation was to determine the suitable spatial arrangement for sunflower and peanut in an intercropping system under different irrigation water amounts and $\mathrm{K}$ fertilizer levels on yield, the land and water equivalent ratios and farmer's net income.

\section{Materials and Methods}

Two field experiments were conducted at the research farm of Ismailia governorate (Latitude $30^{\circ} 35^{\prime} 30^{\prime \prime} \mathrm{N}$, Longitude $32^{\circ} 14^{\prime} 50^{\prime \prime}$ $\mathrm{E}$ and elevation for sunflower and peanut in an intercropping system under different of $10 \mathrm{~m}$ above the sea level), Agricultural Research Center, Egypt during 2016 and 2017 summer seasons. The objective of this investigation was to determine the suitable spatial arrangement irrigation water amounts and potassium (K) fertilizer levels effect on yield production, the land and water equivalent ratios, and farmer's net income. The treatments were the combinations of three irrigation water levels $\left(\mathrm{I}_{1}=0.7, \mathrm{I}_{2}=1.0\right.$ and $\left.\mathrm{I}_{3}=1.2 \mathrm{ETo}\right)$, three $\mathrm{K}$ fertilizer rates $\left(\mathrm{K}_{1}=57, \mathrm{~K}_{2}=\right.$ 86 and $\mathrm{K}_{3}=114 \mathrm{~K}_{2} \mathrm{O} \mathrm{kg} / \mathrm{ha}$ ) and four sunflower and peanut intercropping systems in a strip split plot design with three replications.

The studied intercropping systems were implemented either on raised beds ( $1.2 \mathrm{~m}$ width) or on ridges ( $0.6 \mathrm{~m}$ width). In case of raised beds, peanut seeds were sown in holes on both sides of all the raised beds using two seeds in each hole and the distance between holes were $20 \mathrm{~cm}$. Whereas, in case of cultivation on ridges, peanut seeds were sown on one side only with the above distance.

Sunflower seeds were sown in holes using one seed with 20 or $40 \mathrm{~cm}$ distance depending on the studied system. The studied intercropping systems are presented in Fig. 1 as follows:

$\mathrm{S}_{1}=$ Peanut seeds were sown on all the raised beds. Sunflower seeds were sown above one of the raised beds and the following raised bed was left without intercropping sunflower seeds. The distance between seeds was $20 \mathrm{~cm}$. 


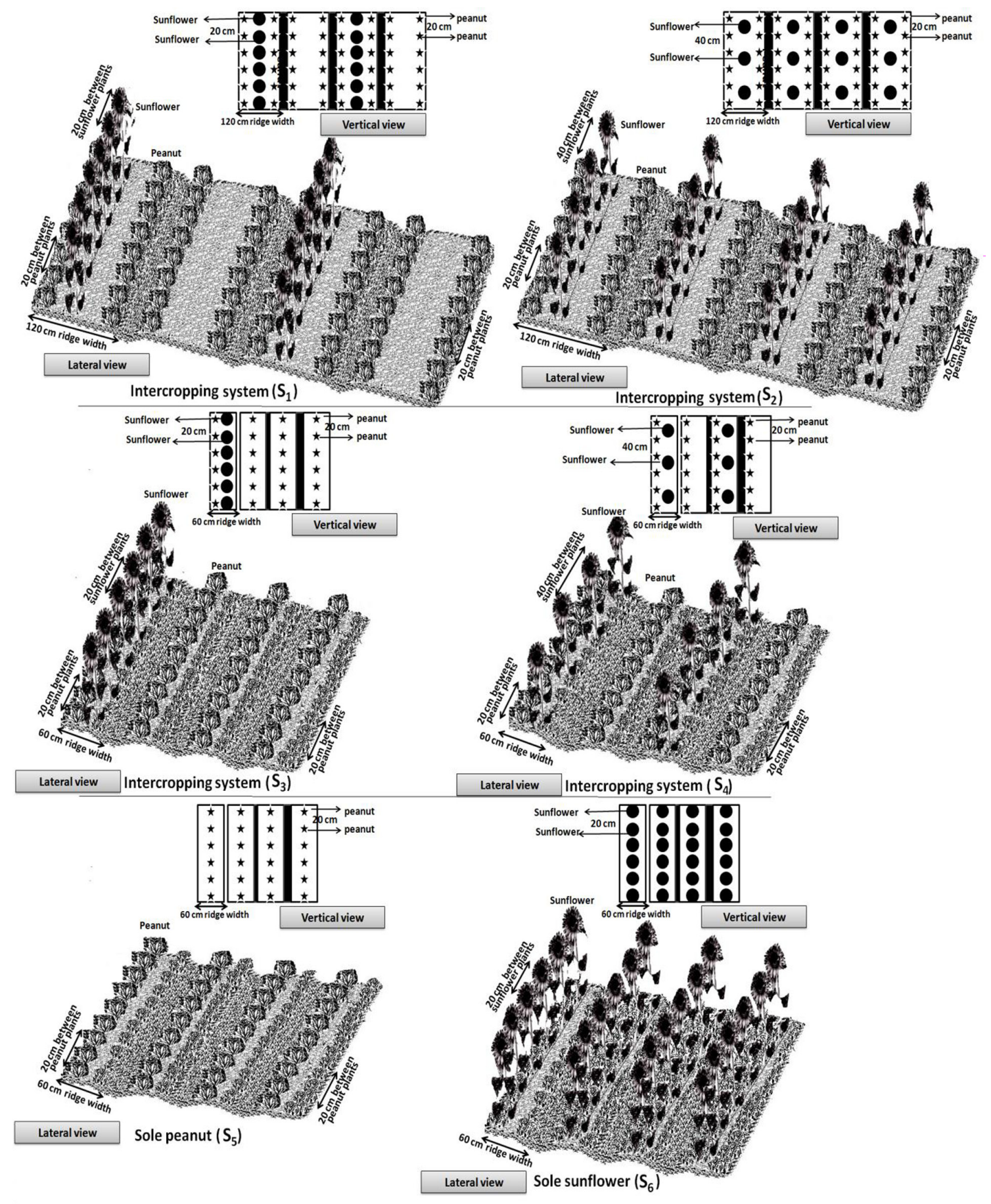

Fig. 1. Intercropping systems of sunflower with peanut and sole cultures of both crops.

$\mathrm{S}_{2}=$ Peanut seeds were sown on all the raised beds. Sunflower seeds were sown above all the raised beds, with $40 \mathrm{~cm}$ distance.

$\mathrm{S}_{3}=$ Peanut seeds were sown on all ridges on one side and sunflower seeds were sown on the other side, with $20 \mathrm{~cm}$ distance. The following three ridges were left without intercropping sunflower seeds.

$\mathrm{S}_{4}=$ Peanut seeds were sown on all ridges on one side and sunflower seeds were sown on the other side with $40 \mathrm{~cm}$ distance. The following ridge was left without intercropping sunflower seeds. 
$\mathrm{S}_{5}=$ Sole peanut was sown with $100 \%$ of its recommended planting density on ridges with $20 \mathrm{~cm}$ planting spacing.

$\mathrm{S}_{6}=$ Sole sunflower was sown with $100 \%$ of its recommended planting density on ridges with $20 \mathrm{~cm}$ planting spacing.

Sole peanut and sole sunflower plants were irrigated with $1.2 \mathrm{ETo}$ and received $\mathrm{K}_{2}\left(86 \mathrm{~K}_{2} \mathrm{O}\right.$ $\mathrm{kg} / \mathrm{ha})$.

The yield and its components for each crop were only used to estimate comparative relationships and did not include in the statistical analysis. The studied sunflower and peanut intercropping patterns were planted with 166,600 and 20,825 plants per hectare, represented $100 \%$ and $25 \%$ of peanut and sunflower recommended planting densities. Irrigation water treatments were randomly assigned to the horizontal plots, $\mathrm{K}$ fertilizer levels were allocated in vertical plots and intercropping systems were distributed in sub plots. Plot area was $21.6 \mathrm{~m}^{2}$. Each sub plot consisted of 12 ridges, $3.0 \mathrm{~m}$ long and $0.6 \mathrm{~m}$ wide or 6 raised beds $3.0 \mathrm{~m}$ long and $1.2 \mathrm{~m}$ wide. The soil of the experimental area is sandy texture with an average bulk density of $1.67 \mathrm{~g} / \mathrm{cm}^{3}$ and is alkaline in reaction with $\mathrm{pH}$ value of 8.20.

Average soil electrical conductivity in the saturated paste extract, over $0-60 \mathrm{~cm}$ depth, was about $0.33 \mathrm{dS} / \mathrm{m}$. The electrical conductivity of irrigation water was $0.50 \mathrm{dS} / \mathrm{m}$ and $\mathrm{pH}$ value was 7.55. Chemical and physical soil analyses were conducted by the standard methods described by Tan (1996). The analysis reveals that available NPK was $10.4,16.9$ and $64.4 \mathrm{ppm}$ in the experimental site. Wheat was the preceding winter crop in both seasons. Calcium super phosphate $(15.5 \%$ $\mathrm{P}_{2} \mathrm{O}_{5}$ ) at rate of $476 \mathrm{~kg} / \mathrm{ha}$ was applied during soil preparation in the two summer seasons. Peanut cultivar Ismailia1 (semi-erect) and sunflower variety Sakha 53 were used and sown on May $26^{\text {th }}$ and May 30 $0^{\text {th }}$ at 2016 and 2017 summer seasons, respectively. In the two seasons, peanut seeds were inoculated by Bradyrhizobium before seeding it. Nitrogen fertilizer was added for sole peanut at a rate of $83.3 \mathrm{~kg} \mathrm{~N} /$ ha as ammonium nitrate $(33.5 \%$ N). Furthermore, nitrogen fertilizer was added for sole sunflower at a rate of $142.8 \mathrm{~kg} \mathrm{~N} / \mathrm{ha}$ as ammonium nitrate. With respect to sunflower intercropped with peanut, nitrogen fertilizer was added at a rate of $120.9 \mathrm{~kg} \mathrm{~N} / \mathrm{ha}$ as ammonium nitrate. Calcium sulfate at the rate of $1190 \mathrm{~kg} / \mathrm{ha}$ was applied for peanut after 35 days from peanut sowing. Recommended cultural practices for growing each crop were implemented as provided by the Egyptian Ministry of Agriculture.

\section{The studied traits}

\section{Peanut studied traits}

At harvest, the following traits were measured on represented ten guarded plants from each sub plot: plant height $(\mathrm{cm})$, pod weight per plant $(\mathrm{g})$ and shelling percentage. Pod yield of peanut per hectare (ton) was recorded on the basis of experimental plot area by harvesting all plants of each sub plot. Seed samples of fifty grams were grinded into fine powder and stored in brown glass bottles for oil seed content according to the method described by A.O.A.C. (1995). Oil yield per hectare $(\mathrm{kg})$ was calculated by multiplying seed oil content $(\%)$ by seed yield per hectare $(\mathrm{kg})$.

\section{Sunflower studied traits}

At harvest, the following traits were measured on represented ten guarded plants from each sub plot: Plant height $(\mathrm{cm}), 1000$ seed weight $(\mathrm{g})$ and seed yield per head (g). Seed yield per hectare $(\mathrm{kg})$ was recorded on the basis of experimental sub plot area by harvesting all plants of each plot. Seed samples of fifty grams were grinded into fine powder and stored in brown glass bottles for oil seed content determination according to the method described by A.O.A.C. (1995). Oil yield per hectare $(\mathrm{kg})$ was calculated by multiplying seed oil content $(\%)$ by seed yield per hectare $(\mathrm{kg})$.

\section{Land equivalent ratio (LER)}

Feng et al. (2016) indicated that "LER refers to the ratio between the benefit from the mixedcropping of two or more than two crops in the same field and the benefit from the monoculture of every crop".

$$
\mathrm{LER}=\left(\mathrm{Y}_{\mathrm{ab}} / \mathrm{Y}_{\mathrm{aa}}\right)+\left(\mathrm{Y}_{\mathrm{ba}} / \mathrm{Y}_{\mathrm{bb}}\right)
$$

where: $\mathrm{Y}_{\mathrm{aa}}=$ Pure stand yield of crop a (peanut), $\mathrm{Y}_{\mathrm{bb}}=$ Pure stand yield of crop $\mathrm{b}$ (sunflower), $\mathrm{Y}_{\mathrm{ab}}=$ Intercrop yield of crop a (peanut) and $\mathrm{Y}_{\mathrm{ba}}=$ Intercrop yield of crop b (sunflower).

\section{Water relation measurements}

Irrigation water was applied every three days using the drip lateral lines connected to the sub-main line. Each lateral line is $20 \mathrm{~m}$ long and spaced at $0.7 \mathrm{~m}$ on the sub-main and is equipped 
with build-in emitters of $2 \mathrm{~L} / \mathrm{h}$ discharge rate spaced at $0.3 \mathrm{~m}$ on the lateral lines. A differential pressure tank was connected to the drip irrigation system to inject fertilizer via irrigation water. Evapotranspiration values (ETo) were calculated using BISm model (Snyder et al., 2004). The amounts of applied irrigation water were calculated according to the equation given by Vermeiren \& Jopling (1984) as follows:

$$
\mathrm{AIW}=\frac{\text { ETo } \times \text { I }}{\operatorname{Ea}(1-\mathrm{LR})}
$$

where: AIW = depth of applied irrigation water $(\mathrm{mm}), \mathrm{ETo}=$ reference evapotranspiration $(\mathrm{mm} /$ day). $\mathrm{I}=$ irrigation intervals (days), $\mathrm{Ea}=$ irrigation application efficiency of drip system (Ea $=90 \%$ in the first seasons and $93 \%$ in the second season). $\mathrm{LR}=$ leaching requirements $(10 \%)$. Crop water use was estimated by the method of soil moisture depletion according to Majumdar (2002) as follows:

$$
\mathrm{WCU}=\sum_{\mathrm{i}=1}^{\mathrm{i}-4} \frac{\theta 2-\theta 1}{100} \times \operatorname{Bd} \mathrm{xd} \quad[3]
$$

where: $\mathrm{WCU}=$ Water consumptive use or actual evapotranspiration, ETo $(\mathrm{mm}), \mathrm{i}=$ Number of soil layer, $\theta 2=$ Soil moisture content after irrigation, ( $\%$, by mass), $\theta 1=$ Soil moisture contents just before irrigation, (\%, by mass), $\mathrm{Bd}=$ Soil bulk density $\left(\mathrm{g} / \mathrm{cm}^{3}\right)$ and $\mathrm{d}=$ Depth of soil layer $(\mathrm{mm})$.

Water equivalent ratio was also calculated. As stated by Mao et al. (2012), "water equivalent ratio quantify the amount of water that would be needed in single crops to achieve the same yield as produced with one unit of water in intercrop" as follows:

$$
\begin{aligned}
& \mathrm{WER}=\mathrm{WER}_{\mathrm{A}}+\mathrm{WER}_{\mathrm{B}}=\left[\left(\mathrm{Yint}_{\mathrm{A}}, \mathrm{WU}_{\mathrm{int}}\right) /\right.
\end{aligned}
$$

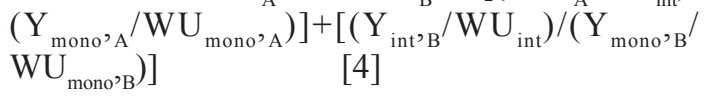

where: $\mathrm{WU}_{\text {int }}, \mathrm{WU}_{\text {mono } \mathrm{A}}$ and $\mathrm{WU}_{\text {mono } \mathrm{B}}=$ Water use efficiency of whole intercropping system, $A$ and $\mathrm{B}$ in monocultures, respectively, $\mathrm{Y}_{\text {int }}, \mathrm{Y}_{\text {mono'A }}$ and $Y_{\text {int } B}=$ Yield of whole intercropping system, A and $\mathrm{B}$ in monocultures, respectively.

If the WER $>1$, it suggests that water utilization of intercropping is higher than that of monoculture. If WER $<1$, it shows that water utilization of intercropping is lower than that of monoculture (Mao et al., 2012).

\section{Farmer net returns}

Farmer's benefit (US\$) was calculated as a difference between total net returns from intercropping and sole crops. Sunflower and peanut seeds prices presented by Bulletin of Statistical Cost Production and Net Return (2017) were used. Net returns were calculated by subtraction the sum of fixed cost of peanut plus variable costs of both crops according to irrigation water treatments and $\mathrm{K}$ fertilizer levels and intercropping systems.

\section{Statistical analysis}

Analysis of variance of the obtained results of each season was performed. The homogeneity test was conducted of error mean squares and accordingly, the combined analysis of the two experimental seasons was carried out. The measured variables were analyzed by ANOVA. Mean comparisons were performed using the least significant differences (L.S.D) test with a significance level of 5\% (Gomez \& Gomez, 1984). The presented results are combined results of yield and its components, as well as, LER, water relations and farmer net returns of the two growing seasons.

\section{Results}

Effect of irrigation water amounts, potassium fertilizer, intercropping systems and their interactions on peanut

The results in Table 1 indicate that pods weight per plant, shelling percentage, and seed oil content were significantly affected by irrigation water treatments, potassium fertilizer levels $(\mathrm{K})$ and the interaction between irrigation water treatments and potassium fertilizer levels. Whereas, pod and oil yields per hectare were significantly affected by irrigation water treatments and potassium fertilizer levels only. Application of 1.0ETo and $\mathrm{K}_{3}$ fertilizer recorded the highest shelling percentage. However, the highest pods weight per plant and seed oil content were obtained by the interaction of 1.2ETo and $\mathrm{K}_{3}$ fertilizer. Plant height was not significantly affected by the studied treatments. Pod yield and its attributes were not significantly affected by intercropping systems. Furthermore, these attributed were not significantly affected by the interaction between irrigation water treatments, potassium fertilizer levels, and intercropping systems. In addition, there were no significant differences between application of 1.0 and the 1.2ETo for all the studied peanut traits. 


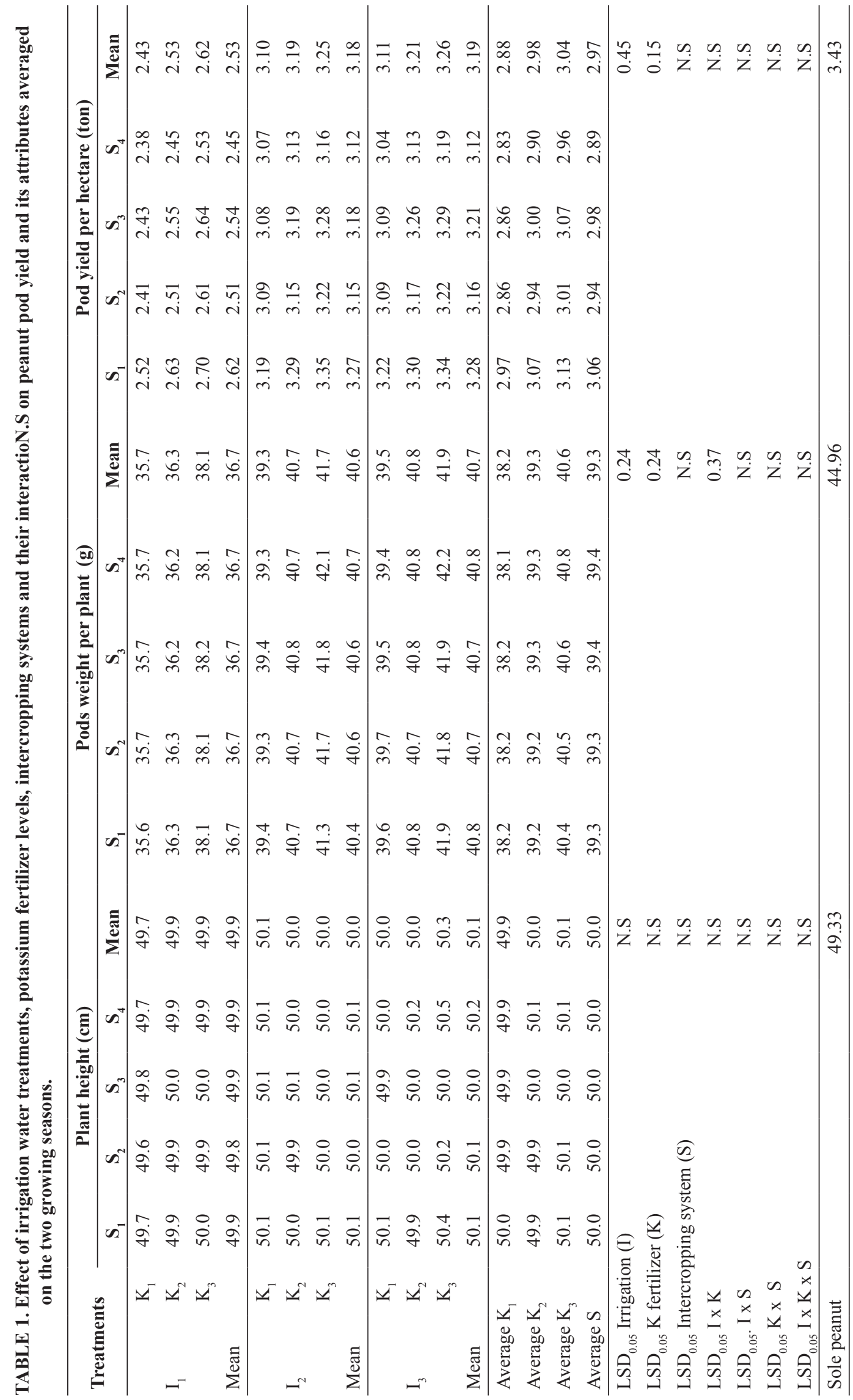

Egypt. J. Agron. Special Issue (2018) 


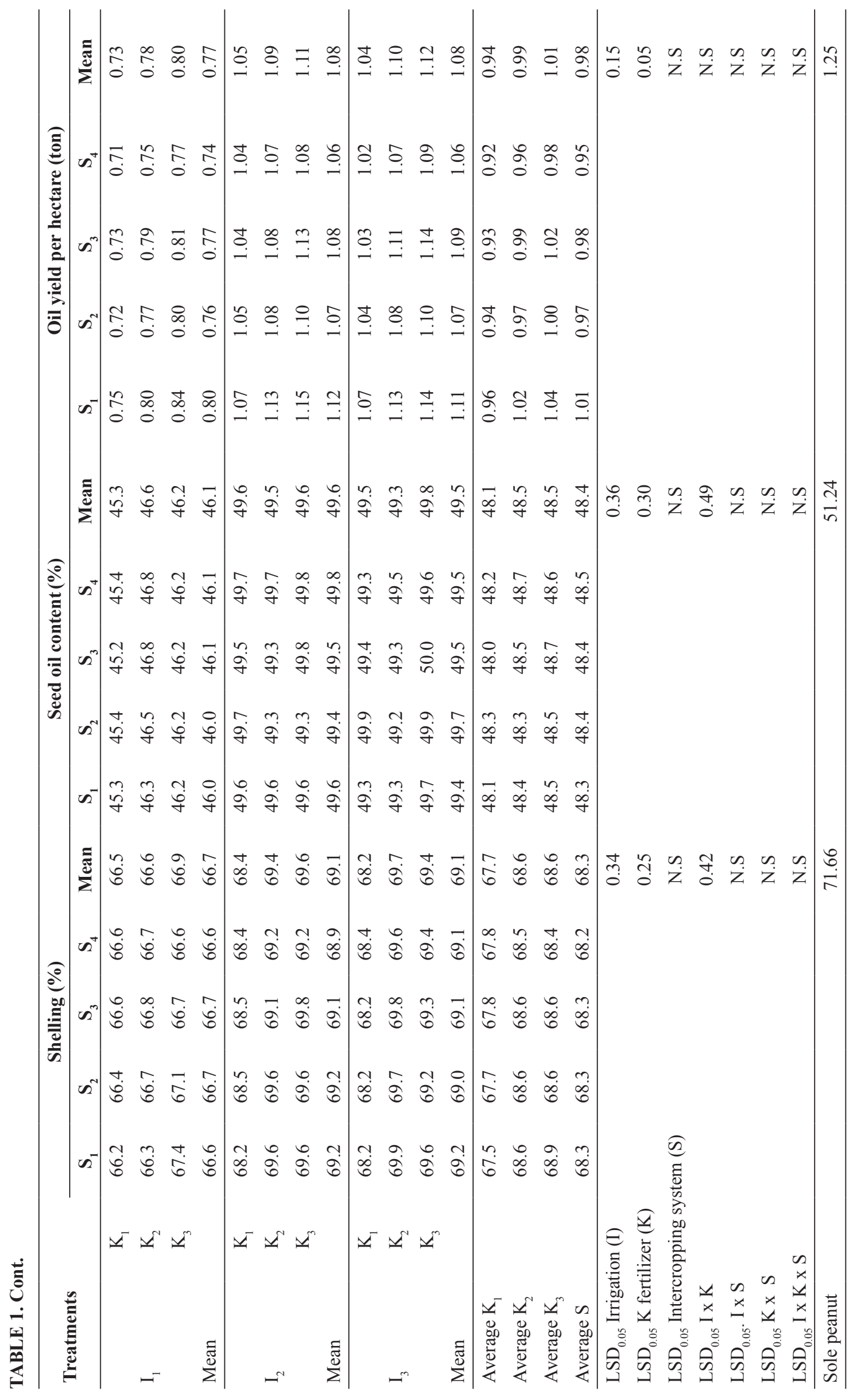

Egypt. J. Agron. Special Issue (2018) 
With respect to application of $0.7 \mathrm{ETo}$, pods weight per plant, pod yield per hectare, shelling percentage, oil content in the seed and oil yield per hectare were significantly reduced by 10.89 , $26.08,3.59,7.37$ and $40.25 \%$, respectively, compared to the values obtained from application of 1.2ETo. With respect to the $\mathrm{K}_{2}$ fertilizer, pods weight per plant, pod yield per hectare and oil yield per hectare were significantly decreased by $3.30,2.01$ and $2.02 \%$, respectively, in comparison with those of $\mathrm{K}_{3}$ fertilizer. Comparison between sole and intercropped peanut reveal that pod yield and its attributes were reduced by intercropping system, except for plant height. The reduction in intercropped peanut yield was found to be $13 \%$, compared to sole peanut.

Effect of irrigation water treatments, potassium fertilizer levels, intercropping system and their interactions on sunflower

The results in Table 2 indicate that plant height was significantly affected by the irrigation treatments, potassium levels, intercropping systems, the interaction between irrigation and potassium levels, and the interaction between irrigation treatments and intercropping systems. Furthermore, 1000 seed weight had similar trend as plant height, except for the interaction between irrigation treatments and intercropping systems. Similarly, head seed weight was significantly affected by irrigation treatments, potassium levels, the interaction between irrigation treatments and potassium levels, the interaction between irrigation treatments and intercropping systems, as well as the interaction between irrigation treatments, potassium levels and intercropping systems. In addition, seed and oil yields per hectare were significantly affected by irrigation water treatments, potassium fertilizer levels and intercropping systems. Finally, seed oil content was significantly affected by irrigation treatments, potassium levels and the interaction between both of them. Increasing the amount of applied water from 0.7 to $1.2 \mathrm{ET}$ caused significant increase in all the studied sunflower traits. The results also show that there were no significant differences between the application of 100 and 1.2ETo on plant height, seed yield per hectare, seed oil content and oil yield per hectare in the data of both growing seasons. With respect to 0.7ETo, 1000 seed weight, head seed weight, seed yield per hectare, seed oil content and oil yield per hectare were significantly decreased by $13.14,7.14$, $50.00,3.52$ and $55.10 \%$, respectively, compared with the values obtained under 1.0ETo (Table 2). Moreover, there were no significant differences between $\mathrm{K}_{2}$ and $\mathrm{K}_{3}$ fertilizer on plant height, seed and oil yields per hectare. $\mathrm{S}_{1}$ Intercropping system had the highest plant height, 1000 seed weight, and head seed weight, seed yield, and oil yield per hectare, compared to $\mathrm{S}_{2}$ and $\mathrm{S}_{3}$. The interaction between 1.0ETo and $\mathrm{K}_{3}$ fertilizer resulted in the highest plant height and seed oil content, compared to the other interaction. However, the highest 1000 seed weight and head seed weight were obtained by the interaction between 1.2ETo and $\mathrm{K}_{3}$ fertilizer. The interaction between application of 1.2 ETo and $\mathrm{S}_{1}$ intercropping system recorded the highest head seed weight, compared to the others. In addition, the interaction between 1.2ETo, $\mathrm{K}_{3}$ fertilizer and $\mathrm{S}_{1}$ intercropping system recorded the highest 1000-seed weight and head seed weight compared to the others.

\section{Relative yield and land equivalent ratio (LER)}

The results in Table 3 indicate that the relative yield of peanut was significantly affected by irrigation water treatments, and potassium levels, whereas relative yield of sunflower was significantly affected by irrigation water treatments, potassium levels and intercropping systems. LER was significantly affected by irrigation water treatments, potassium fertilizer, intercropping systems and the interaction between irrigation water treatments and potassium. fertilizer levels. The value of LER was 0.87 for $\mathrm{S}_{4}$ intercropping system that received irrigation amount of 0.7ETo and $\mathrm{K}_{1}$ fertilizer. It was 1.36 for $\mathrm{S}_{1}$ intercropping system that received irrigation amount of 1.2ETo and $\mathrm{K}_{3}$ fertilizer, thus, land productivity was increased by $36 \%$ (Table 3 ).

\section{Water relations of peanut and sunflower systems}

Water consumptive use and water equivalent ratio were significantly affected by irrigation treatments, potassium levels and by the interaction between irrigation treatments and potassium levels. An increase in water consumptive use of peanut and sunflower intercropping system occurred when the applied irrigation water was increased from 0.7 to $1.2 \mathrm{ETo}$ (Table 4).

In all the studied intercropping systems, the values of water equivalent ratio were higher than 1. Under the application of $0.7 \mathrm{ETo}, \mathrm{K}_{1}$ fertilizer and $\mathrm{S}_{4}$ intercropping systems, the lowest values of water equivalent ratio were obtained. Whereas, the highest values of water equivalent ratio were 
obtained under the application of 1.2ETo, $\mathrm{K}_{3}$ fertilizer and $\mathrm{S}_{1}$ intercropping system. Thus, an increase in the value of the productivity of the unit of water between $52-56 \%$ can be obtained under 1.2ETo, $\mathrm{K}_{3}$ fertilizer and $\mathrm{S}_{1}$ intercropping system (Table 4).

\section{Farmer revenue}

The total and net incomes of intercropping sunflower with peanut as compared to sole peanut is shown in Table 5. The income of peanut was significantly affected by irrigation treatments only, whereas the income of sunflower, total income and net income were significantly affected by irrigation treatments, potassium levels and intercropping systems. The interaction between irrigation treatments and potassium levels were significantly affect the total income. Total income of intercropped sunflower with peanut varied between treatments from US\$ 1195 to 1767 per hectare as compared with sole peanut (US\$ 1557 per hectare). Furthermore, net income of intercropped sunflower with peanut varied between treatments from US\$ 608 per hectare $(0.7$ ETo, $\mathrm{K}_{1}$ fertilizer and $\mathrm{S}_{4}$ intercropping system) to US\$1142 per hectare (1.2ETo, $\mathrm{K}_{3}$ fertilizer and $\mathrm{S}_{1}$ intercropping system) as compared to sole peanut (US\$ 943 per hectare), which is more profitable than sole peanut cultivation for Egyptian farmers.

\section{Discussion}

The few previous studies on intercropping sunflower with peanut in Egypt dealt with either the appropriate sunflower planting density (Abd El-Zaher et al., 2009 and El-Mehy et al., 2018) and/or appropriate irrigation amounts (El-Mehy et al., 2018). Thus, this investigation was done with the aim to determine the suitable arrangement for sunflower and peanut in an intercropping system, the required irrigation water amounts, and the required potassium fertilizer. For peanut, application of 0.7 ETo resulted in reduction pods weight per plant, pod yield per hectare, shelling percentage, seed oil content and oil yield per hectare. This result could be attributed to water stress reduced vegetative and reproductive growth through its effects on reducing number and size of leaves, as well as pollination and seed growth. In this concern, Junjittakarn et al. (2014) reported that photosynthesis and plant growth were reduced as a result of water deficits, which negatively affected seed formation and development, total seed yield, pods per plant and seeds per pod (Arruda et al., 2015). Our results show that there was no significant difference between the application of 1.0 and 1.2ETo on plant height, pod weight per plant, pod yield per ha, shelling, seed oil content and oil yield per ha, which offer an opportunity to save on the applied irrigation water under weather and soil condition of our experiment. The above peanut traits were increased by increasing irrigation water and $\mathrm{K}$ fertilizer, which may be attributed to increase of $\mathrm{K}^{+}$availability in the soil under non water stress conditions. Raza et al. (2013) indicated that transporting of much of the $\mathrm{K}^{+}$through the diffusion process to the root surface is highly dependent on water in the soil. Reddy et al. (2011) also stated that it is directly affecting crop development. In addition, $\mathrm{K}^{+}$plays an important role in hormonal balance, especially increasing auxin level, which an important hormone for plant growth (Rubio et al., 2009). Furthermore, Alaloosy (2002) indicated that $\mathrm{K}^{+}$is an important element in increasing lipids synthesis in oil crops, which explain the increase in seed oil content and oil yield under $\mathrm{K}_{3}$ fertilizer.

Our results also indicate that application of 1.0ETo and $\mathrm{K}_{3}$ fertilizer recorded the highest seed yield per plant and shelling percentage. However, the highest values of pods weight per plant, and seed oil content were obtained by the interaction of 1.2ETo and $\mathrm{K}_{3}$ fertilizer. This could be attributed to availability of water in rhizophere area, which increase of $\mathrm{K}^{+}$availability. Nájera et al. (2015) indicated that there is a coupling mechanism between irrigation and fertilizer, where irrigation changes soil moisture contents, thus influences the transformation of fertilizer. The evidenced beneficial effect of $\mathrm{K}^{+}$fertilization on peanut crop in our experiment was due to the low levels of exchangeable $\mathrm{K}^{+}$in the sandy soil the experimental plots. Therefore, increased peanut seed production under $\mathrm{K}_{3}$ fertilizer could be related to the known role of $\mathrm{K}^{+}$in many physiological and metabolic processes, including photosynthesis, osmoregulation, transport of nutrients, transport and storage of carbohydrates, nitrogen absorption and synthesis of proteins (Raza et al., 2014).

The results also show that application of $\mathrm{K}_{3}$ fertilizer did not help peanut plants to withstand the imposed water stress, where yield and its attributes were highly deceased, compared to the application of more water and $\mathrm{K}$ fertilizer. 


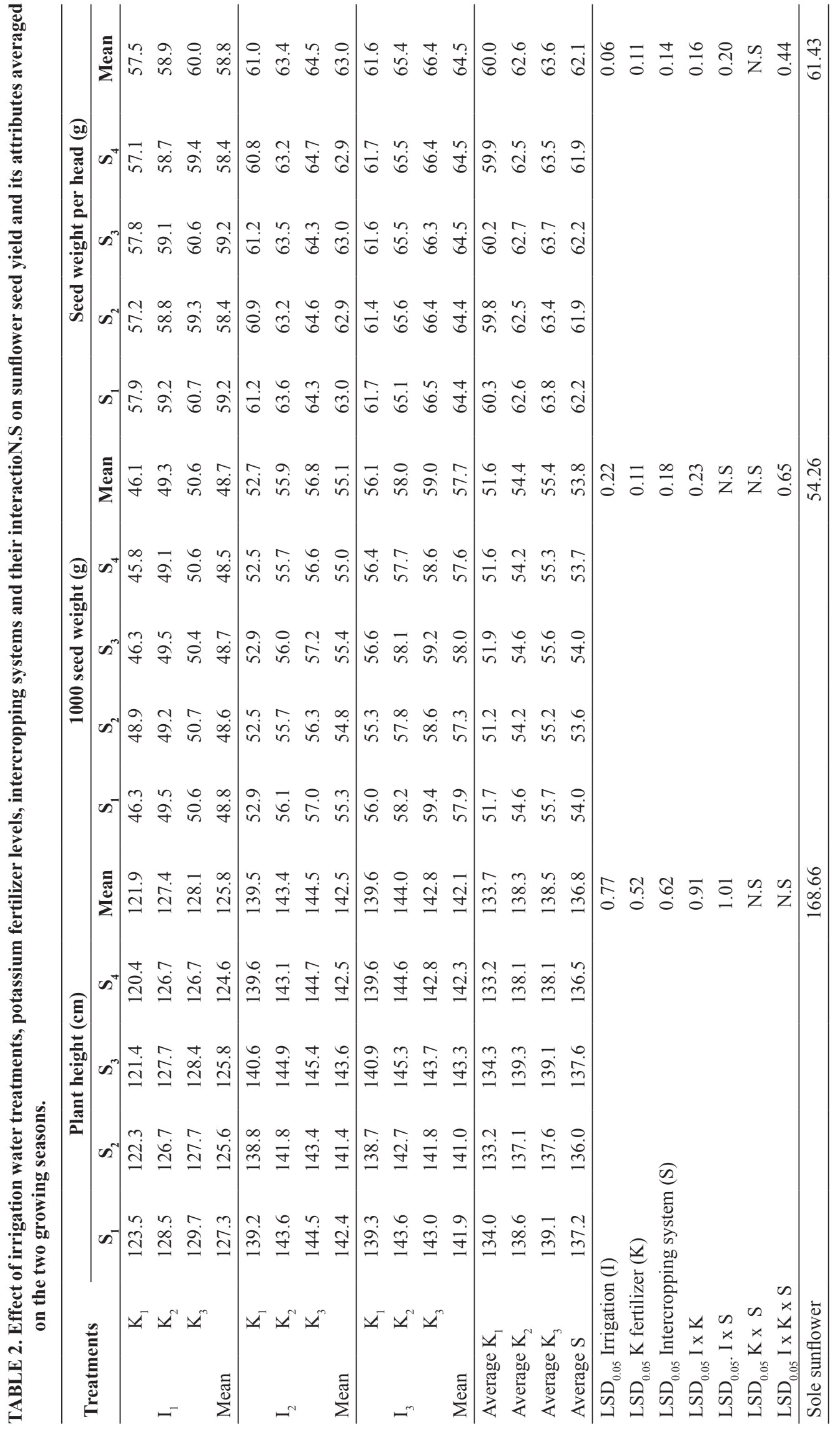

Egypt. J. Agron. Special Issue (2018) 


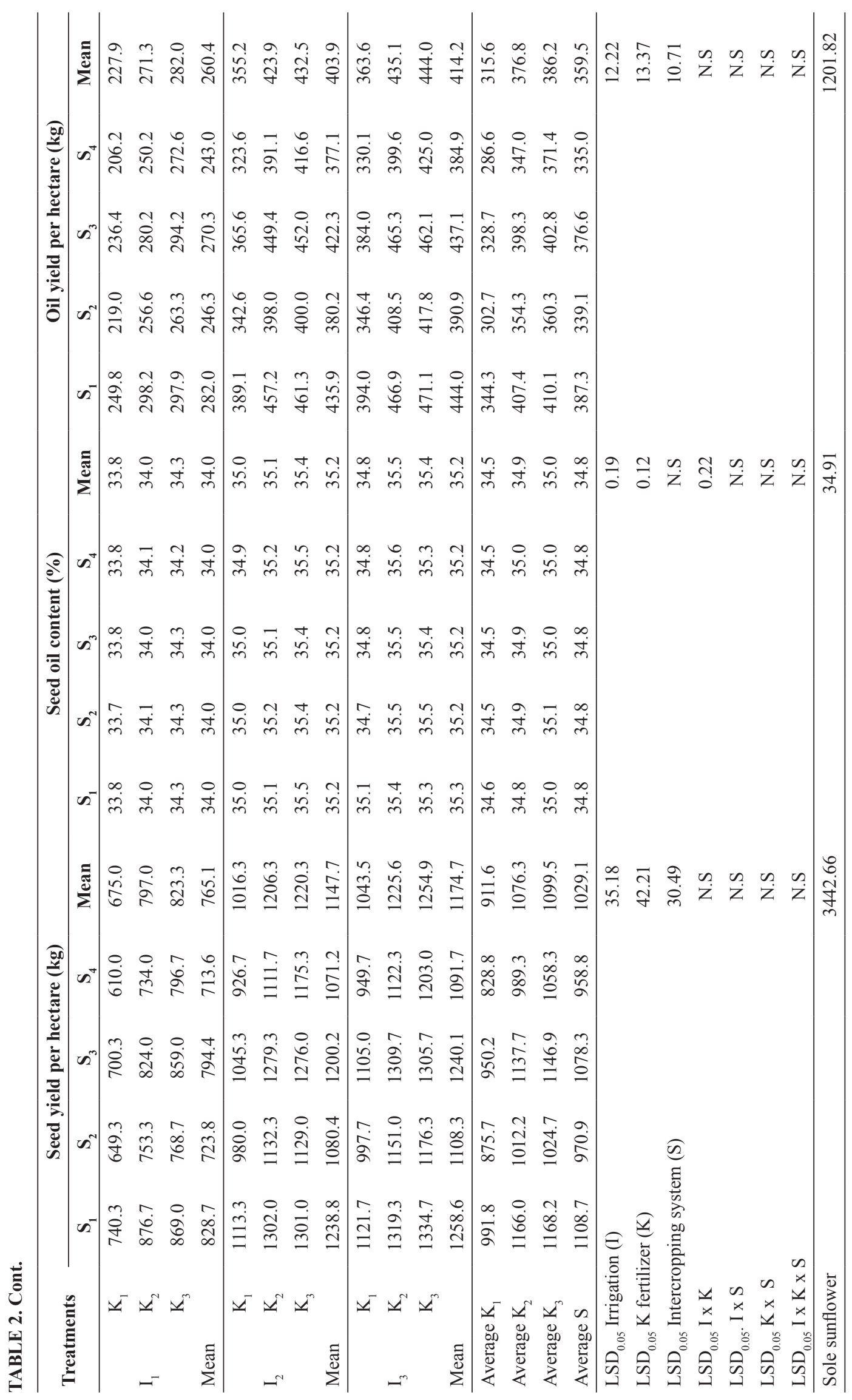

Egypt. J. Agron. Special Issue (2018) 


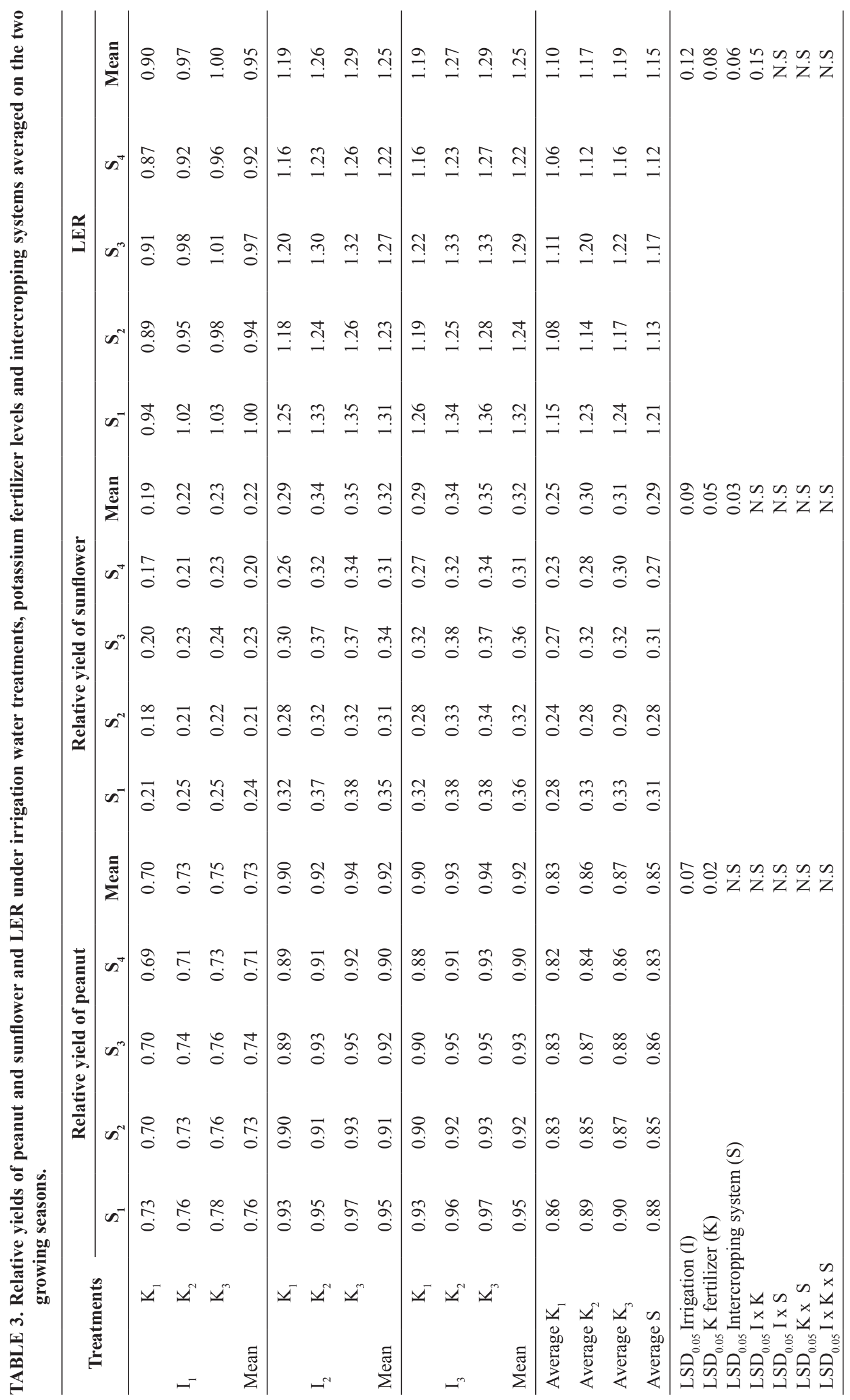

Egypt. J. Agron. Special Issue (2018) 


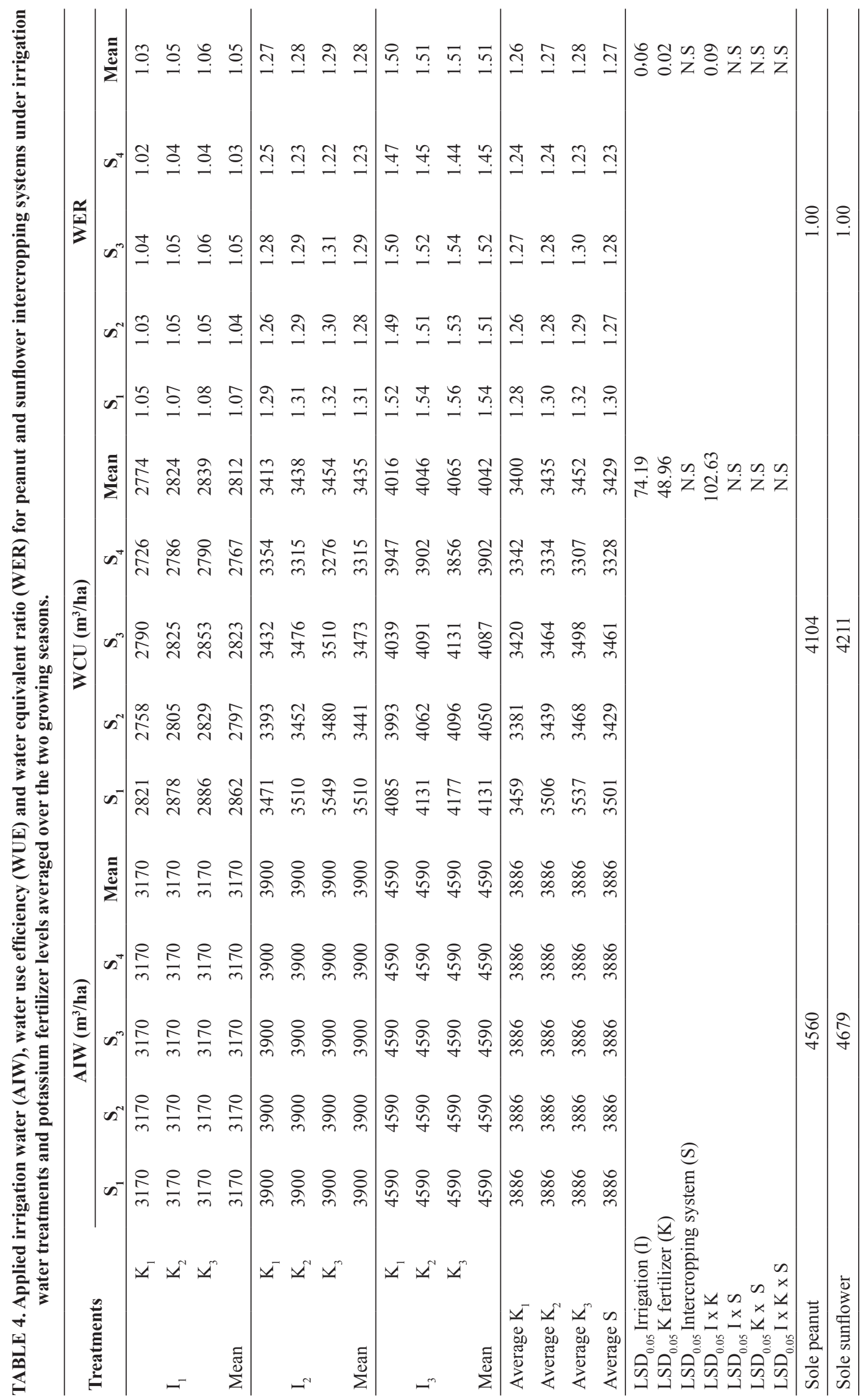




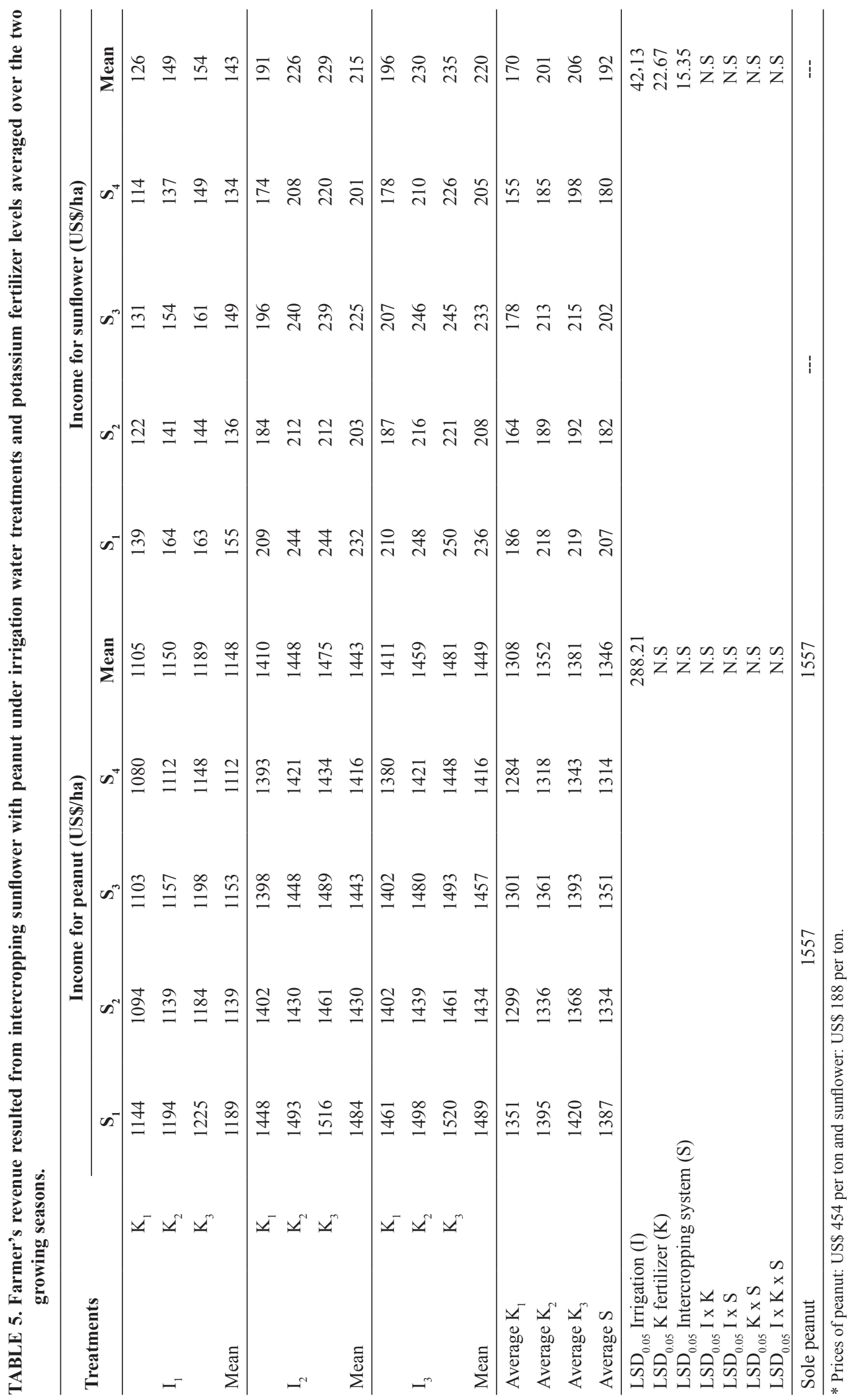

Egypt. J. Agron. Special Issue (2018) 


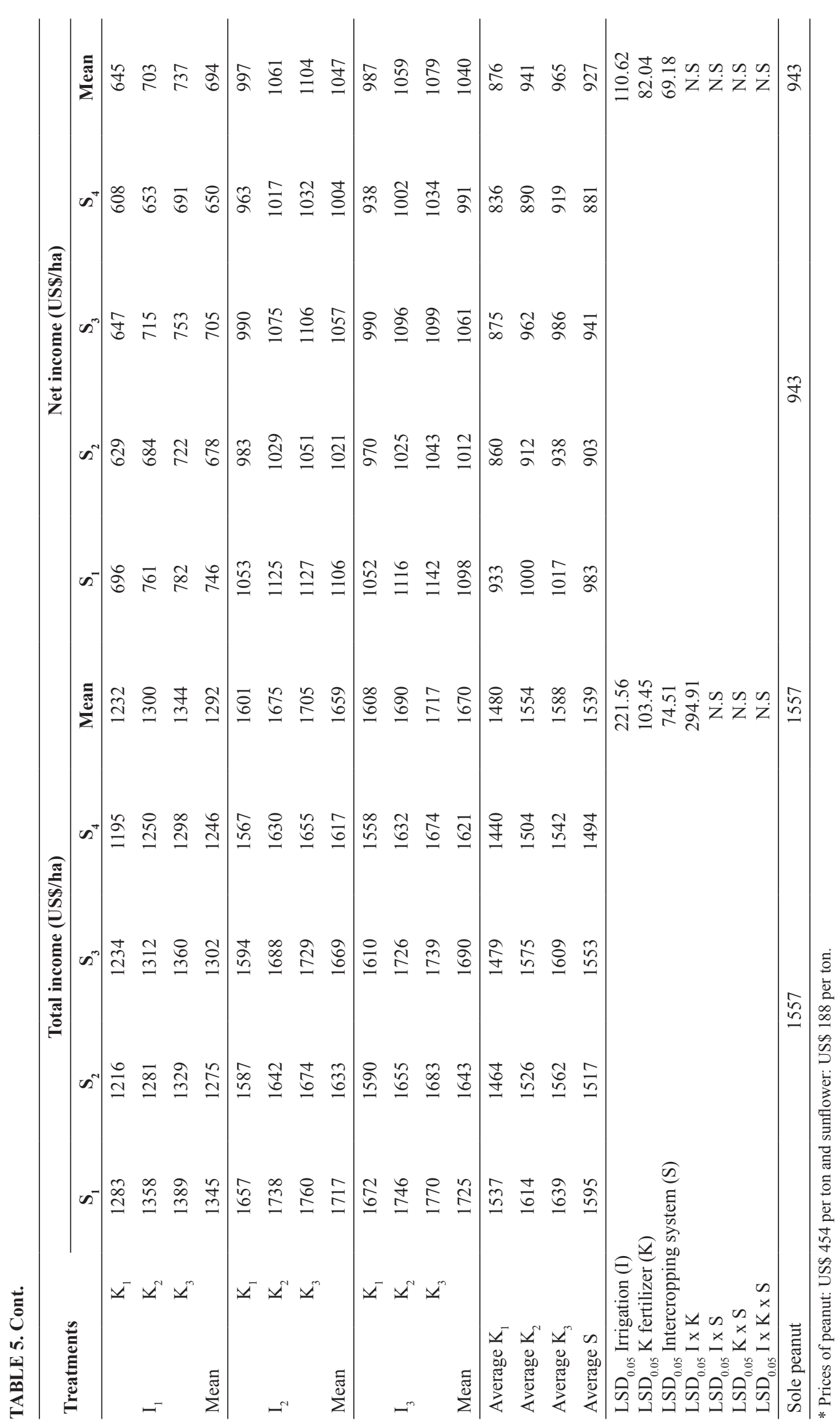

Egypt. J. Agron. Special Issue (2018) 
Our results indicate that there is an increase in peanut plant height under intercropping system, compared to peanut sole planting. This result could be attributed to application of $\mathrm{K}_{3}$ fertilizer, whereas the sole peanut plants received $\mathrm{K}_{2}$ fertilizer. Pradyut et al. (2006) and Almeida et al. (2015) observed a beneficial effect of $\mathrm{K}^{+}$on peanut plant height. Also, our results reveal that reductions in intercropped peanut yield and its attributes were found in all intercropping systems, except for plant height, compared to sole peanut. Competition between sunflower and peanut for light, as sunflower has taller and erect plants, compare to peanut might negatively affected photosynthesis process for intercropped peanut, compared to sole peanut plants.

Application of 0.7ETo reduced the yield and its attributes of sunflower. Similar results were obtained by Alahdadi et al. (2011) and Buriro et al. (2015) who reported that 1000 seed weight, seed oil content and seed yield per hectare was reduced with reducing the applied irrigation amounts. Abdel-Mawgoud et al. (2009) indicated that small root system were observed in sunflower plants grown under water deficit, which resulted in weak shoot growth and this, in turn, reduce both the vegetative growth and the final yield. Increasing applied irrigation water from 0.7 to 1.2ETo caused significant increases in plant height, 1000 seed weight, head seed weight, seed yield per hectare, seed oil content and oil yield per hectare. Taha \& Abbass (2008) reported that the response of plant height, head seed weight and seed yield per hectare was found to be linearly related to the amount of irrigation.

Our results also show that there were no significant differences between the application of 100 and 1.2ETo on plant height, seed yield per hectare, seed oil content and oil yield per hectare. Therefore, under the weather and soil condition of our experiments, water saving can be attain through application of 1.0ETo instead of 1.2ETo. The results indicate that sunflower yield and its attributes significantly increased by increasing $\mathrm{K}$ fertilizer. These results are supported by Faisal et al. (2013) and Ertiftik \& Zengin (2016) for 1000 seed weight, head seed weight, seed yield per hectare, see oil content and oil yield per hectare. Furthermore, Soleimanzadeh et al. (2010) showed that increasing $\mathrm{K}^{+}$fertilizer increased oil content in sunflower seeds.
The interaction between irrigation water treatments and potassium fertilizer levels was found significant for sunflower seed yield and its attributes. Application of $\mathrm{K}_{3}$ fertilizer did not relief water stress caused by application of $0.7 \mathrm{ETo}$ in sunflower, which resulted in reduction in seed yield and its attributes compared to the other studied irrigation water treatments. Moreover, there were no significant differences between $\mathrm{K}_{2}$ and $\mathrm{K}_{3}$ fertilizer on sunflower seed and oil yields per hectare. This finding can be useful in reducing production cost. Similar results were obtained by Taha \& Abbass (2008).

The results also reveal that the spatial arrangements of sunflower plants in the studied intercropping systems affected both peanut and sunflower yield, even though sunflower planting density was similar in all intercropping systems ( $25 \%$ of its recommended planting density). The yield of both peanut and sunflower were reduced in $\mathrm{S}_{2}$ followed by $\mathrm{S}_{4}$ compared to $\mathrm{S}_{1}$ followed by $\mathrm{S}_{3}$. Regarding to peanut, it seems that the shading effects of sunflower plants were lower under $S_{1}$ followed by $\mathrm{S}_{3}$.

Nevertheless, sunflower seed yield was high under $S_{1}$ and $S_{3}$, which can be attributed to closeness of sunflower plants to each other and thereby facilitated pollination process more than in $\mathrm{S}_{2}$ and $\mathrm{S}_{4}$. Furthermore, Yadav et al. (2002) indicated that because sunflower pollen is heavy and sticky it cannot be carried by wind. Yang et al. (2015) stated that appropriate distance between two component crops in an intercropping system had an effect on the yield of both crops. Moreover, Zhang et al. (2011) stated that when interspecific competition is lower than intra-specific, high yields are achieved with intercropping. In addition, sunflower spatial arrangements in $S_{1}$ intercropping system had the highest values of plant height, 1000 seed weight and head seed weight, seed and oil yields per hectare, compared to the others intercropping systems. Similar results were obtained by El-Mehy et al. (2018), where they intercropped 25,33 and $50 \%$ of recommended sunflower planting density with peanut. They found that intercropping sunflower with peanut with $25 \%$ of its planting density reduce competition between peanut and sunflower plants on resources, thus achieved the highest yield of both crops.

Our results indicate that the highest values 
of relative yields, land equivalent ratio, water equivalent ratio, farmer's total and net income were obtained from using $1.2 \mathrm{ETo}, \mathrm{K}_{3}$ fertilizer level under $\mathrm{S}_{1}$ intercropping system, followed by $1.0 \mathrm{ETo}, \mathrm{K}_{3}$ fertilizer under $\mathrm{S}_{1}$ intercropping system. Similar results were obtained by El-Mehy et al. (2018).

\section{Conclusion}

Our results revealed that to obtain the highest peanut yield under intercropping it with sunflower, peanut seeds should be sown on both sides of all the raised beds ( $1.2 \mathrm{~m}$ width) with $20 \mathrm{~cm}$ planting spacing (two plants together) in its recommended planting density. In addition, sunflower seeds should be sown on one row above the raised beds, with $20 \mathrm{~cm}$ planting spacing (one plant) and the following bed should be left without intercropping sunflower seeds $\left(\mathrm{S}_{1}\right.$ intercropping system). This intercropping system can reduce competition between sunflower and peanut plants. Likewise, this intercropping system should be irrigated with $1.2 \mathrm{ETo}$ and received $114 \mathrm{~K}_{2} \mathrm{O}$ fertilizer to obtain the highest value of land equivalent ratio, water equivalent ratio and farmer's net income. Application of 1.0ETo with $114 \mathrm{~K}_{2} \mathrm{O}$ fertilizer under $\mathrm{S}_{1}$ intercropping system produced slightly lower value of peanut and sunflower yield, LER, WER and farmer's net income, compared to its counterpart values of 1.2 ETo.

\section{References}

A.O.A.C. (1995) "Official Methods of Analysis", $16^{\text {th }}$ ed. Assoc. Official Agric. Chemists, Washington, D.C.

Abd El-Zaher, S.R., Mohamadain, E.E. and Atalla, R.A.A. (2009) Effect of intercropping sunflower with peanut under different rates of nitrogen fertilization on yield components of both crops. Mansoura Univ. J Agric Sci. 34(3), 2097-2114.

Abdel-Mawgoud, A.S.A., Gameh, M.A., Abd-Elaziz, S.H. and El-Sayed, M.M. (2009) Sunflower water relations at various irrigation regimes with modern irrigation systems under climatic conditions of Assiut Governorate, Upper Egypt. $13^{\text {th }}$ Int Water Tech Conf. IWTC 13 2009, Hurghada, Egypt, pp. 589-609.

Alahdadi, I., Oraki, H. and Khajani, F.P. (2011) Effect of water stress on yield and yield components of sunflower hybrids. Afr. J. Biotech. 10(34), 65046509 .

Alaloosy, Y.A.M. (2002) Effect of interaction between application of $\mathrm{K}, \mathrm{N}$ and $\mathrm{P}$ fertilizer on growth and yield of sunflower. Iraqi J. Agric. Sci. 3(33), 99-112.

Almeida, H.J., Pancelli, M.A., Prado, R.M., Cavalcante, V.S. and Cruz, F.J.R. (2015) Effect of potassium on nutritional status and productivity of peanuts in succession with sugarcane. J. Soil Sci. Plant Nut. 15(1), 1-10.

Arruda, I.M., Moda-Cirino, V., Buratto, J.S. and Ferreira, J.M. (2015) Growth and yield of peanut cultivars and breeding lines under water deficit. Pesq Agropec Trop Goiânia, 45(2), 146-154.

Asadi, S. (2010) Influence of different K fertilizer sources on sunflower production. 19 $9^{\text {th }}$ World Congress of Soil Science, Soil Solutions for a Changing World. 1 - 6 August 2010, Brisbane, Australia.

Buriro, M., Sanjrani, A.S., Chachar, Q.I., Chachar, N.A., Chachar, S.D., Buriro, B., Gandahi, A.W. and Mangan, T. (2015) Effect of water stress on growth and yield of Sunflower. J. Agric. Techno. 11(7), 1547-1563.

Bulletin of Statistical Cost Production and Net Return (2017) Summer and Nili Field Crops and Vegetables and Fruit, Agriculture Statistics and Economic Sector. Ministry of Egyptian Agriculture and Land Reclamation, Part (2), August 2017, Egypt.

El-Mehy, Amira A., Taha, A.M. and Abd-Allah, A.M.M. (2018) Maximizing land and water productivity by intercropping sunflower with peanut under sprinkler irrigation. Alex Sci. Exchange J. 39(1), 144-160.

El-Sawy, W.A., El-baz, M.G. and Toaima, S.E.A. (2006) Response of two peanut varieties to intercropping with sunflower under different sunflower sowing dates. Arab J. Nuclear Sci. Appl. 21(3), 193-210.

Ertiftik, H. and Zengin, M. (2016) Response of sunflower to potassium and magnesium fertilizers in calcerous soils in central Anatolia of Turkey. $J$. Plant Nut. 39(12), 1734-1744.

Faisal, M.A., Yahya, K.J. and Saad, A.M.A. (2013) Effect of date and quantity of potassium fertilizer Application on growth, yield and oil quality of 
sunflower Helianthus annuus L. var. Flame. J. Agric. Veterinary Sci. 4(1), 33-40.

Feng, L., Sun, Z., Zheng, M., Muchoki, M., Zheng, J., Yang, N., Bai, W., Feng, CH., Zhang, Z., Cai, Q. and Zhang, D. (2016) Productivity enhancement and water use efficiency of peanut-millet intercropping. Pak. J. Bot. 48(4), 1459-1466.

Genc, L., Inalpulat, M., Kizil, U., Mirik, M., Smith, S.E. and Mendes, M. (2013) Determination of water stress with spectral reflectance on sweet corn (Zea mays L.) using classification tree (CT) analysis. Zemdirbyste-Agric. 100 (1), 81-90.

Gomez, K.A. and Gomez, A.A. (1984) "Statistical Procedures for Agricultural Research", $2^{\text {nd }}$ ed. John Willey and Sons, Toronto, ON, Canada.

Hawkesford, M., Horst, W., Kichey, T., Lambers, H., Schjoerring, J., Moller, I.S. and White, P. (2012) Functions of macronutrients: Potassium. In: "Marschner's Mineral Nutrition of Higher Plants" Marschner, Petra (Ed.), pp.178-189. Elsevier, Adelaide.

Junjittakarn, J., Girdthai, T., Jogloy, S., Vorasoot, N. and Patanothai, A. (2014) Response of root characteristics and yield in peanut under terminal drought condition. Chilean J. Agric. Res. 74(3), 249-256.

Kadasiddappa, M.M., Rao, V.P., Reddy, K.Y., Ramulu, V., Devi, M.U. and Reddy, S.N. (2017) Effect of irrigation (drip/surface) on sunflower growth, seed and oil yield, nutrient uptake and water use efficiency - A review. Agric. Rev. 38(2), 152-155.

Krishnamurthy, L., Vadez, V., Jyotsna, D., Serraj, M., Niga, R., Sheshshayee, S. and Aruna, S. (2007) Variation in transpiration efficiency and its related traits in a groundnut (Arachis hypogaea L.) mapping population. Field Crop Res. 103, 189-197.

Majumdar, D.K. (2002) "Irrigation Water Management: Principles and Practice", $2^{\text {nd }}$ ed. Prentice-Hall of India, New Delhi- 110001. 487p.

Mao, L.L., Zhang, L.Z., Li, W.W., Werf, W.V.D., Sun, J.H., Spiertz, H. and Li, L. (2012) Yield advantage and water saving in maize/pea intercrop. Field Crops Res. 138, 11-20.

Medranoa, H., Tomása, M., Martorella, S., Flexasa, J.,
Hernándeza, E., Rossellóa, J., Poub, A., Escalonaa, J. and Botaa, J. (2015) From leaf to whole-plant water use efficiency (WUE) in complex canopies: Limitations of leaf WUE as a selection target. The Crop J. 3(3), 220-228.

Nájera, F., Tapia, Y., Baginsky, C., Figueroa, V., Cabeza, R. and Salazar, O. (2015) Evaluation of soil fertility and fertilisation practices for irrigated maize (Zea mays L.) under Mediterranean conditions in Central Chile. J. Soil Sci Plant Nut. 15(1), 84-97.

Ouda, S. and Zohry, A. (2018) Cropping pattern to face water scarcity. In: "Cropping Pattern to Overcome Abiotic Stresses: Water, Salinity and Climate". Springer Publishing House.

Umar, S. (2006) Alleviating adverse effects of water stress on yield of sorghum, mustard and groundnut by potassium application. Pakistan Journal of Botany, 38(5), 1373-1380.

Pradyut, C., Samui, R.C. and Bordolui, S.K. (2006) Growth, yield attributes and yield of different cultivars of groundnut as affected by potassium application. J. Crop Weed, 2, 37-39.

Raza, M.A.S., Saleem, M.F., Shah, G.M., Jamil, M. and Khan, I.H. (2013) Potassium applied under drought improves physiological and nutrient uptake performances of wheat (Triticum aestivun L.). J. Soil Sci. Plant Nutr. 13, 175-185.

Raza, M.A.S., Saleem, M.F., Shah, G.M., Khan, I.H. and Raza, A. (2014) Exogenous application of glycinebetaine and potassium for improving water relations and grain yield of wheat under drought. $J$. Soil Sci and Plant Nut. 14, 348-364.

Reddy, S.T., Reddy, D.S. and Reddy, G.P. (2011) Fertilizer management for maximizing productivity and profitability of export oriented groundnut (Arachis hypogaea L.). J. Res Angrau. 39, 83-85.

Rubio, V., Bustos, R., Irigoyen, M.L., Cardona-López, X., Rojas-Triana, M. and Paz-Ares, J. (2009) Plant hormones and nutrient signaling. Plant Molecular Bio. 69, 361-373. DOI: 10.1007/s11103-008-9380-y.

Sezen, S.M., Yazar, A., Kapur, B. and Tekin, S. (2011) Comparison of drip and sprinkler irrigation strategies on sunflower seed and oil yield and quality under Mediterranean climatic conditions. Agric. Water Manag. 98, 1153-1161. 
Soleimanzadeh, H., Habibi, D., Ardakani, M.R., Paknejad, F. and Rejali, F. (2010) Response of sunflower (Helianthus annuus L.) to drought stress under different potassium levels. World Applied Sci. J. 8(4), 443-448.

Sorensen, R.B. and Butts, C.L. (2014) Peanut response to crop rotation, drip tube lateral spacing, and irrigation rates with deep subsurface drip irrigation. Sci. 41, 111-119.

Snyder, R.L., Orang, M., Bali, K. and Eching, S. (2004) Basic irrigation scheduling BISm [online]. [Access 01.01.2011] Available at: http://www.waterplan. water.ca.gov/landwateruse/wateruse/Ag/CUP/ California/cClimate_Data_010804.xls.

Taha, A. (2012) Effect of climate change on wheat and maize crops grown in new reclaimed land under fertigation practice. $P h D$. Thesis. Collage of Agriculture, Tanta University, Egypt.

Taha, M.M. and Abbass, J.A. (2008) Effect of potassium fertilization and irrigation intervals on growth and yield of sunflower Helianthus annuus L. Jordan J. Agric. Sci. 4(2), 207-216.

Tan, K.H. (1996) "Soil Sampling Preparation and Analysis". Marcel Dekker, New York.

Veeramani, P. and Subrahmaniyan, K. (2012) Physical and economic optimum of response model for NPK application in irrigated groundnut (Arachis hypogaea L.). The Madras Agric. J. 99, 526-529.
Vermeiren, L. and Jopling, G.A. (1984) Localized Irrigation. FAO, Irrigation and Drainage Paper no. 36 , Rome, Italy.

Yadav, R.N., Sinha, S.N. and Singhal N.C. (2002) Honeybee (Apis spp.) pollination in sunflower hybrid seed production: Effect of planting design on honeybee movement and its operational area. Apimondia Standing Commission of Pollination and Bee Flora. http://www.apimondia.org/apiacta/ slovenia/en/yadav.pdf.

Yang, F., Wang, X., Liao, D., Lu, F., Gao, R., Liu, W. and Yang, W. (2015) Yield response to different planting geometries in maize-soybean relay strip intercropping systems. Agronomy Journal, 107, 296-304.

Zhang, G., Yang, Z. and Dong, S. (2011) Interspecific competitiveness affects the total biomass yield in an alfalfa and corn intercropping system. Field Crops Res. DOI:10.1016/j.fcr.2011.06.006.

Zhu, H., Lamb, M.C., Butts, C.L. and Blankenship, P.D. (2004) Improving peanut yield and grad with drip system in undulating fields. Transactions of the ASAE. 47(1), 99-106. 


\section{نظم تحميل دوار الشمس على الفول السودانى تحت كميات رى ومستويات مختلفة من التسميد البوتاسيى لدوان

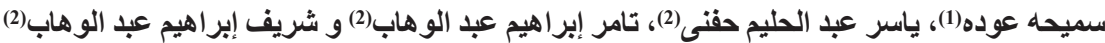

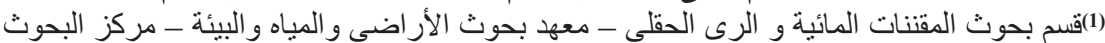

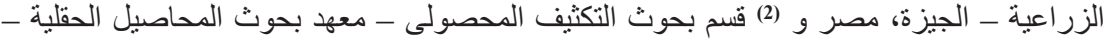 مركز البحوث الزر اعية ــ الجيزة - مصر.}

أقيمت تجربتان حقليتان بمحطة البحوث والتجارب ـ مركز البحوث الزر اعية بالإسماعيلية - مصر خلال

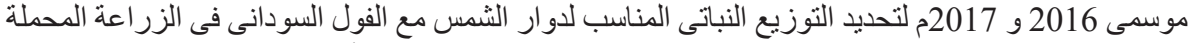

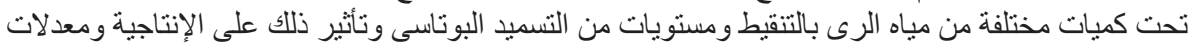

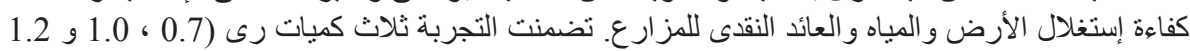

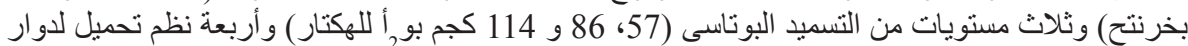

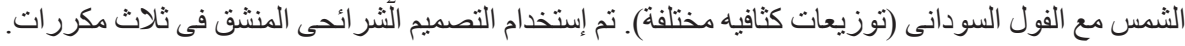
أشارت النتائج إلى عدم وجود إختلافات معنوية بين معاملة 1.0 و 1.2 بخرنتح على معظم صفات صفات

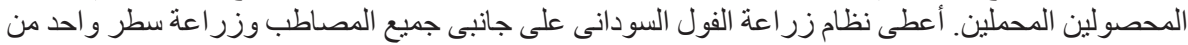

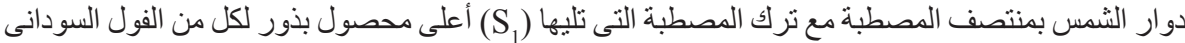

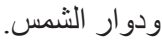

توصى الدر اسة بإستخدام 1.2 بخرنتح و التسميد بمعدل 114 كجم بو أ للهكتار عند زر اعة الفول الفول السودانى

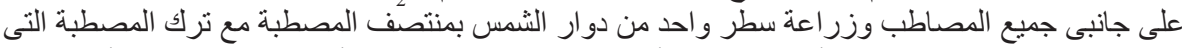
تليها بدون تحميل للحصول على أعلى إنتاجية وأعلى معدل لكفاءة إستخدام الأرض والئل المياه وكذلك أعلى عائد نقدى للمزارع. 